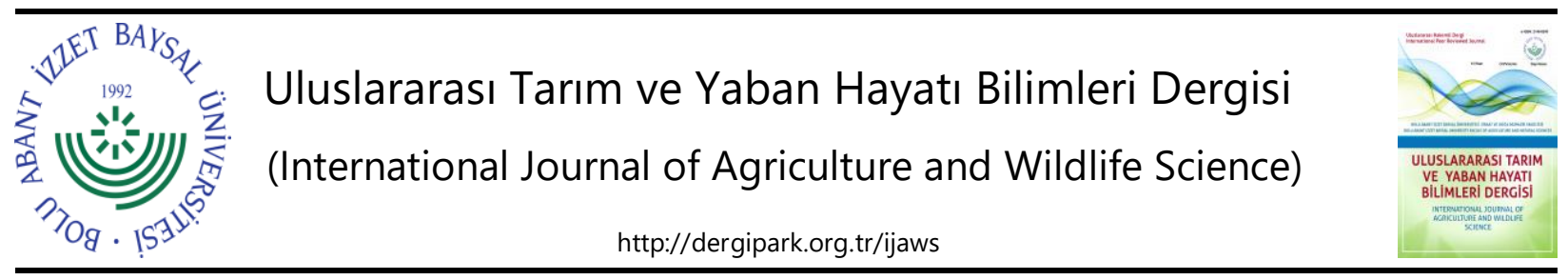

Araştırma Makalesi

\title{
II. Ürün Mısır Çeşitlerinde Organik ve İnorganik Gübre Uygulamasının Verim ve Kaliteye Etkisi ile Ekonomik Analizi
}

\author{
Serap Doğan, Veysi Acıbuca, Yusuf Doğan* \\ Mardin Artuklu Üniversitesi, Kızltepe Meslek Yüksekokulu, Bitkisel ve Hayvansal Üretim Bölümü, Mardin \\ Geliş tarihi (Received): 28.07.2020Ｋabul tarihi (Accepted): 11.11.2020
}

\begin{abstract}
Anahtar kelimeler:
II. ürün, mısır, verim, kalite, ekonomik analiz

Özet. Bu araştırma 2015 ve 2016 yıllarında II. ürün olarak Mardin ili Göllü köyünde Tesadüf Bloklarında Bölünmüş Parseller' deneme desenine göre üç tekerrürlü olarak yürütülmüştür. Çalışmada materyal olarak farklı iki mısır çeşidi (Dekalp-5401 ve LG 30.597) kullanılmıştır. Uygulama olarak; gübresiz kontrol parseli (G0), standart ticari gübre $8 \mathrm{~kg} \mathrm{da}^{-1} \mathrm{P}_{2} \mathrm{O}_{5}, 20 \mathrm{~kg} \mathrm{da}^{-1} \mathrm{~N}(\mathrm{G} 1)$, tavuk gübresi $1000 \mathrm{~kg} \mathrm{da}^{-1}$ (G2), çiftlik gübresi $1500 \mathrm{~kg} \mathrm{da}^{-1}$ (G3) ve solucan gübresi $1200 \mathrm{~kg} \mathrm{da}^{-1}$ (G4) olacak şekilde kullanılmıştır. Araştırmanın iki yıllık ortalama sonuçlarına göre, en yüksek tane verimi $1219.2 \mathrm{~kg} \mathrm{da}^{-1}$ ile Ç1 (Dekalb 5401) çeşidinin G1 (ticari gübre) verilen parsellerinde elde edilmiştir. Organik gübre ortalama değeri ise $1124.4 \mathrm{~kg} \mathrm{da}^{-1}$ ile Ç2 (LG 30.597) çeşidinin G2 (tavuk gübresi) uygulamasında elde edilmiştir. Kalite parametreleri bakımından çeşit ve gübre uygulamalarının hektolitre, yağ oranı ve protein oranına etkisi önemsiz bulunurken, incelenen diğer parametrelere etkisi ise önemli bulunmuştur. Ekonomik karlıık bakımından kullanılan her iki çeşitte de konvansiyonel gübre uygulamalarının daha avantajlı olduğu tespit edilmiştir. Çeşitler arasında konvansiyonel gübre uygulamaları bakımından Ç1 çeşidinin (Dekalb 5401) kârlıık düzeyi daha yüksek olmuştur. Organik gübre uygulamaları bakımında yapılan değerlendirmede Ç2 çeşidinin (LG 30.597) daha kârlı olduğu ortaya çıkmıştır. Ticari gübre uygulamaların diğer gübre uygulamalarına göre maliyeti düşük ve elde edilen verim miktarının daha yüksek olmuştur. Bölgemizde yeterli düzeyde organik mısır piyasasının oluşmaması nedeniyle ticari gübrelerin ekonomik olarak daha avantajlı olduğu sonucuna varıımıştır.
\end{abstract}

\section{The Effect and Economic Analysis of Organic and Inorganic Fertiliser Applications on Yield and Quality of the 2nd Product Corn Varieties}

\section{Keywords:}

2nd product, corn, yield, quality, economic analysis

\begin{abstract}
This research was carried out in 2015 and 2016 as a second product in Mardin province, Göllü village, with three replications according to the trial pattern of the Divided Blocks in Coincidence Blocks. Two different types of corn (Dekalp-5401 and LG 30.597) were used as the material in this study. In the application; manure-free control parcel (G0), standard commercial fertilizer $8 \mathrm{~kg} \mathrm{da}^{-1}$ $\mathrm{P}_{2} \mathrm{O}_{5}, 20 \mathrm{~kg} \mathrm{da}^{-1} \mathrm{~N}\left(\mathrm{G} 1\right.$ ), chicken manure $1000 \mathrm{~kg} \mathrm{da}^{-1}$ (G2), farm manure $1500 \mathrm{~kg} \mathrm{da}^{-1}$ (G3) and worm manure $1200 \mathrm{~kg} \mathrm{da}^{-1}$ (G4) were used. According to the two-year average results of the research, the highest grain yield was obtained in the plots of G1 (commercial fertilizer) of Ç1 (Dekalb 5401) cultivar with $1219.2 \mathrm{~kg} \mathrm{da}^{-1}$. The average value of organic fertiliser was obtained in G2 (chicken manure) application of Ç2 (LG 30.597) variety with $1124.4 \mathrm{~kg} \mathrm{da}^{-1}$. In terms of quality parameters, the effect of cultivar and fertiliser applications on hectolitre, oil ratio and protein ratio was found insignificant, while the effect on other parameters examined was found significant. It has been determined that conventional fertiliser applications are more advantageous in both types used in terms of economic profitability. While the profitability level of the varieties Ç1 (Dekalb 5401) was higher in terms of conventional fertiliser applications, it was revealed that Ç2 varieties (LG 30,597) were more profitable in the evaluation made in terms of organic fertiliser applications. It has been concluded that commercial fertilisers are more economically advantageous due to the low cost of commercial fertiliser applications, higher yields, and no organic corn prices in the application area.
\end{abstract}




\section{GíRiş}

Mısıın kullanım alanlarının başında insan gıdası ve endüstri hammaddesi gelmektedir. Mısırın sap ve yaprakları özellikle silaj şeklinde hayvan yemi olarak değerlendirilmekte, yine sap ve yaprakları sanayide kâğıt yapımı ve küçük çapta hasır el işleri yapımında da değerlendirilmektedir. Mısır ana kullanım alanlarının yanı sıra özel varyete gruplarında çerezlik olarak da tüketilmektedir. Mısıın özel kullanım alanları içerisinde yağ ve tatlandırıcı sektörü ile biyoyakıt-biyoetanol üretimi de bulunmaktadır (Öztürk ve ark., 2019). 2019 yılı verilerine göre dünyada 1.109 milyon ton mısır üretimi yapılmış olup, ihracatçı ülke olarak birinci sırada yer alan ABD, mısır tüketiminde \%27'lik bir paya sahiptir (FAO, 2020). Ülkemizde mısır ana ürün ve ikinci ürün olarak ekim alanı bakımından tahıllar içerisinde buğday ve arpadan sonra gelmektedir. Tane mısır, besin elementleri özelliği açısından oldukça önemli olup beslenmede yoğun bir şekilde kullanılmaktadır.

Mısır bir sıcak iklim bitkisidir. Ancak aşırı sıcaklık isteyen bir bitki değildir. Tepe püskülü çıkışı ve tozlanma döneminde sıcaklığının $33^{\circ} \mathrm{C}^{\prime}$ nin üzerine çıkması durumunda döllenme olumsuz etkilenir ve koçanda tane oluşumu düşerek verim kayıplarına neden olmaktadır. Yıllık yağış miktarı 1200-1500 mm aralığında olan bölgelerde maksimum verim elde edilebilir (Kırtok, 1998). Suyu seven bir bitki olan mısır vejatasyon döneminde yaklaşık olarak $500 \mathrm{~mm}$ su ihtiyacı olup, bölgemizde daha önceden yapılan çalışmalarda ortalama 5-6 kez sulanması gerekmektedir (Doğan ve ark., 2019).

Mısır yetiştiriciliği bakımından bölge bazında Ege, Akdeniz ve Güneydoğu Anadolu bölgelerinde yaygın olarak ana ürün ya da ikinci ürün olarak yetiştiricilik yapılmaktadır. Bölgelere uygun melez mısır çeşitlerinin yetiştirilmeye başlanmasıyla, son yıllarda mısır üretiminde önemli artışlar elde edilmiştir. Türkiye'de 639.000 ha ekim alanı, üretim 6.000 .000 ton ve elde edilen verim ise $1062 \mathrm{~kg} \mathrm{da}^{-1}$ olarak gerçekleşmiş olup dünya ortalamasının (580 kg $\mathrm{da}^{-1}$ ) yaklaşık olarak 2 katıdır (FAO, 2020). Ülkemizde mısı üretim alanı olarak 1.345.064 ton ile Konya, 717.802 ton Adana ve 421.130 ton ile Mardin ili gelmektedir (TUIK, 2020). Bitki yetiştiriciliğinde yüksek verim almak için özellikle mısırda yoğun miktarda gübreleme yapılması gerekmektedir. Yoğun olarak kullanılan ticari gübreler toprağa zarar vermesi yanında, gübre fiyatlarının yüksek oluşu çiftçimizi girdi masrafları açısından zorlamaktadır. Diğer taraftan aşırı ve bilinçsizce kullanılan ticari gübreler çevre sorunlarına yol açmakla beraber ekolojik dengeyi olumsuz etkilemekte ve ticari gübre fiyatlarındaki artışlar ile gübre kullanımını kısıtlamaktadır (Sözüdoğru ve ark., 1996). Bölgemizde mısır yetiştiriciliğinde (Güneydoğu Anadolu) aşırı kullanılan kimyasal gübre (800-900 kg ha ${ }^{-1}$ ) toprağın yapısını bozmaktadır (Dogan ve ark., 2015). Ülkemiz de gübre kullanımı her gecen yıl artmakla beraber yanlış gübre kullanımı sonucu ortaya çevre sorunları çıkmaktadır. Ülkemizde 2017 yılı gübre kullanım verilerine göre NPK gübreleri içerisinde \%67 ile en fazla azot (N) tüketildiği görülmektedir (TAGEM, 2020). Tahıllar içerisinde en fazla ekim alanına sahip olmasından dolayı buğdayın azotlu gübre tüketimi fazladır. Arpa ve mısırda ise verim daha da yüksek olup gübrelenen alan açısından tahıllar içerisinde en fazla mısır ekim alanı (\%95.6) gelmektedir (Şahin 2016).

Organik gübreler, ticari gübrelere göre bazı besin elementleri yönünden yüksek olması yanında, toprağın fiziksel, kimyasal ve biyolojik özellikleri açısından toprağı iyileştirici ve koruyucu özelliği, toprağın su tutma kapasitesi ve toprağın agreat yapısına olumlu etki yaparken toprak erozyonuna karşı dirençli olmasını sağlar (Bryan 1968; Özdemir 1991; Sözüdoğru ve ark., 1996; Korkmaz ve ark., 1999). Çiftlik gübresi organik madde ve mikroorganizma kapsamı bakımından toprağa çok yönlü faydalar sağlayan bir gübre çeşididir. Toprağı bitki besin kaynakları bakımından zenginleştirmesi ve çözünen besinlerin bitkiler tarafından alınmasını sağlar (Aydeniz ve Brohi 1991). Tavuk gübresinin bitki besin elementi olarak N, P, K ve diğer makro ve mikro içeriği yönünden oldukça zengin olup uygulanan alanlarda bitki gelişimi üzerinde olumlu etki yapmaktadır. Aşırı kullanılması durumunda toprak tuzluluğu ve bitkilerde toksite etkisine neden olabilir (Başar 2009). Solucan gübresi bitkilerde besin elementi döngüsü ve transformasyonları üzerine olumlu etkisinin yanında toprağın fiziksel, kimyasal ve biyolojik yapısına katkı sunmaktadır (Shen ve Yang 2008).

Bu kapsamda, II. Ürün mısır yetiştiriciliği için uygun çeşidin yanında gübre olarak geleneksel inorganik gübre ile organik gübre kullanımının karşılaştırmalı bir şekilde verim ve kalitelerinin belirlenmesi ile elde edilen verimin kullanılan gübre uygulamasının ekonomik anlamda getirisinin belirlenmesi amaçlanmışıı. Böylelikle insan sağlığının korunması amacıyla kullanımı yaygın olan alternatif organik gübre kaynaklarının bitkide verim ve kalite üzerine etkisi araştırılarak toprağın korunmasının yanında ülke ve bölge ekonomisine katkı sunmak, hedeflenmiştir. 


\section{MATERYAL VE METOT}

Çalışma, Mardin ili Artuklu İlçesine bağı Göllü köyünde iki yıl süreyle (2015 ve 2016 yıllarında) ikinci ürün olarak (Haziran-Kasım dönemi) yürütülmüştür. Materyal olarak iki hibrit mısır çeşidi Dekalb 5401 (Ç1) ve LG 30.597 (Ç2) kullanılmıştır. Deneme "Tesadüf Bloklarında Bölünmüş Parseller" deneme planına göre üç tekrarlamalı olarak kurulmuştur. Çalışmada ana parsellere çeşitler olacak şekilde, alt parsellere ise farklı gübre kaynakları gelecek şekilde uygulanmıştır. Parsel boyutları $6 \times 3.5$ m olacak şekilde $21 \mathrm{~m}^{2 \prime}$ lik her blok 10 parselden oluşmuş ve deneme alanı toplamda 30 parsel olacak şekilde kurulmuştur. Parsel ve bloklar arası $2 \mathrm{~m}$ boşluk olacak şekilde bırakılmıştır.

Buğday hasadından sonra, ekim yapılan alan yağmurlama sulama yöntemi ile toprak tava getirildikten sonra ikinci sınıf toprak işleme aletleri ile sürülerek ekime hazırlanmıştır. Çalışmada;

1. Gübresiz kontrol parseli (G0)

2. Standart ticari gübre $8 \mathrm{~kg} \mathrm{da}^{-1} \mathrm{P}_{2} \mathrm{O}_{5}, 20 \mathrm{~kg} \mathrm{da}^{-1} \mathrm{~N}(\mathrm{G} 1)$

3. Tavuk gübresi $1000 \mathrm{~kg} \mathrm{da}^{-1}(\mathrm{G} 2)$

4. Çiftlik gübresi $1500 \mathrm{~kg} \mathrm{da}^{-1}$ (G3)

5. Solucan gübresi $1200 \mathrm{~kg} \mathrm{da}^{-1}$ (G4)

olacak şekilde kullanılmıştır. Toprak hazır hale getirildikten sonra ekim öncesi $8 \mathrm{~kg} \mathrm{da}^{-1} \mathrm{P}_{2} \mathrm{O}_{5}$ (\%42 TSP) tamamı ekimle birlikte toprağa karıştırılarak verilmiştir. Azotlu gübrenin (\%33 AN) yarısı ekimle birlikte kalan yarısı da sapa kalkma döneminde $(40 \mathrm{~cm})$ verilmiştir. Organik gübreler ekim öncesi ekim yapılacak parsellere eşit gelecek şekilde dağıtılarak tırmık ile toprağa karıştııı Imıştır. Ekim 70 × $20 \mathrm{~cm}$ olacak şekilde elle yapılmıştır Yetiştirme süresi boyunca bitkinin sulama, çapalama, boğaz doldurma, hastalık ve zararlılarla mücadele gibi bakım işlemleri düzenli olarak yapılmıştır. Hasat ve ölçümler parsel yanlarından birer sıra, başlardan ise $50 \mathrm{~cm}$ kenar tesiri olarak atıldıktan sonra kalan alan üzerinde $\left(5 \mathrm{~m} \times 2.1 \mathrm{~m}=10.5 \mathrm{~m}^{2}\right)$ yapılmıştır. Ekim işlemi her iki yılda 28.06.2015 ve 28.06 .2016 tarihlerinde yapılmıştır. Denemenin hasadı ilk yıl 28.10.2015 tarihinde, ikinci yıl ise 25.10.2016 tarihinde yapılmıştır. Ekimden hasat dönemine kadar toplamda 6 kez sulanmıştır. Sulama takvimi olarak;

1. Ekim yapıldıktan sonra çıkış döneminde

2. Birinci ara çapa döneminde

3. İkinci ara çapa döneminde

4. İkinci azotlu gübre döneminde

5. Tepe püskülü öncesi döneminde

6. Süt olum döneminde

Çalışmanın yürütüldüğü dönemi kapsayan aylara ait iklim verileri, uzun yıllar ortalaması ve yıllara ait iklimsel veriler, Mardin Meteoroloji Müdürlüğü'nden temin edilmiş ve bu veriler Çizelge 1'de sunulmuştur (Anonim, 2020).

Çizelge 1. Mardin ilinde uzun yıllar yağış ortalaması (1960-2016), çalışma yıllarına ait sıcaklık, yağış ve nem değerleri.

Table1. Mardin province Long Years Average Precipitation (1960-2016), Precipitation, temperature and humidity values of working years

\begin{tabular}{lccccccccc}
\hline \multirow{2}{*}{ Aylar } & \multicolumn{3}{c}{ Sıcaklık $\left({ }^{\circ} \mathbf{C}\right)$} & \multicolumn{3}{c}{ Yağış (mm) } & \multicolumn{3}{c}{ Nispi Nem (\%) } \\
\cline { 2 - 10 } & $\mathbf{2 0 1 5}$ & $\mathbf{2 0 1 6}$ & UYO & $\mathbf{2 0 1 5}$ & $\mathbf{2 0 1 6}$ & UYO & $\mathbf{2 0 1 5}$ & $\mathbf{2 0 1 6}$ & UYO \\
\hline Haziran & 25.9 & 26.2 & 25.6 & 2.9 & 1.0 & 4.7 & 29.0 & 28.2 & 32.3 \\
Temmuz & 31.8 & 30.6 & 29.9 & 0,2 & 0.1 & 1.3 & 19.6 & 22.4 & 27.7 \\
Ağustos & 30.5 & 32.2 & 29.5 & 0.4 & 1.4 & 0.2 & 25.8 & 21.7 & 28.4 \\
Eylül & 28.4 & 24.3 & 25 & 9.9 & - & 1.8 & 23.0 & 28.7 & 32.6 \\
Ekim & 19.5 & 20.5 & 18.4 & 58.2 & 16.5 & 32.9 & 49.6 & 33.3 & 45.1 \\
Toplam & & & & 71.6 & 18.0 & 40.9 & & & \\
Ortalama & 27.2 & 26.8 & 25.7 & & & & 29.4 & 26.9 & 32.4 \\
\hline
\end{tabular}

UYO: Uzun yıllar ortalaması.

Çizelge 1'de görüldüğü gibi denemenin yapıldığı 2015 yılında toplam yağış uzun yıllar ortalamasından yüksek olurken, 2016 yılında ise 18.0 mm ile uzun yıllar ortalamasından düşük gerçekleşmiştir. Ortalama sıcaklıklar her iki yılda UYO'dan yüksek olmuştur. Nispi nem bakımından da denemenin yürütüldüğü yıllarda ortalama değerler, uzun yıllar ortalamalarından daha düşük olarak gerçekleşmiştir.

Çalışmanın yapıldığı alana ait toprak özellikleri alüvyal ana materyalli, eğim düz ve düze (\%0.0-1.0) yakın, kırmızı renkli ve killi tekstür yapıya sahip olup toprakların fiziksel ve kimyasal özellikleri çizelge 2 'de verilmiştir. 
Çizelge 2. Deneme alanı topraklarının bazı fiziksel ve kimyasal özellikleri.

Table2. Some physical and chemical properties of the trial area soils.

\begin{tabular}{ccccccccccc}
\hline $\begin{array}{c}\text { Derinlik } \\
(\mathbf{c m})\end{array}$ & $\begin{array}{c}\text { Kum } \\
(\%)\end{array}$ & $\begin{array}{c}\text { Silt } \\
(\%)\end{array}$ & $\begin{array}{c}\text { Kil } \\
(\%)\end{array}$ & Tekstür & $\mathbf{p H}$ & $\begin{array}{c}\text { Kireç } \\
(\%)\end{array}$ & $\begin{array}{c}\text { Fosfor } \\
\left(\mathbf{k g ~ d a}^{-1}\right)\end{array}$ & $\begin{array}{c}\text { Potasyum } \\
\left(\mathbf{k g ~ d a}^{-1}\right)\end{array}$ & $\begin{array}{c}\text { Organik } \\
\text { Madde (\%) }^{(\%)}\end{array}$ & $\begin{array}{c}\text { Toplam } \\
\text { Tuz (\%) }\end{array}$ \\
\hline $0-30$ & 38.17 & 27.75 & 34.08 & Killi-Tınl & 7.95 & 14.46 & 2.81 & 34.20 & 1.42 & 0.042 \\
\hline
\end{tabular}

Temin edilen gübreler ekim öncesi örnekleri alınarak Mardin Artuklu Üniversitesi Araştırma Merkezi laboratuvarında analizleri yapılmış ve elde edilen sonuçlar; çizelge 3 'te verilmiştir.

Çizelge 3. Araştırmada kullanılan tavuk, çiftlik ve solucan gübrelerinin özellikleri.

Table3. Characteristics of chicken manure, farm manure and worm manure that used in the research.

\begin{tabular}{lccc}
\hline Özellikler & Tavuk gübresi & Çiftlik gübresi & Solucan gübresi \\
\hline \% Organik madde & 54.3 & 45.2 & 48.3 \\
\% Azot $(\mathrm{N})$ & 3.64 & 2.85 & 2.23 \\
\% Fosfor $\left(\mathrm{P}_{2} \mathrm{O}_{5}\right)$ & 1.63 & 1.65 & 1.18 \\
\% Potasyum $\left(\mathrm{K}_{2} \mathrm{O}\right)$ & 1.38 & 1.35 & 1.52 \\
$\%$ Organik karbon & 33.6 & 27.3 & 25.3 \\
pH & 6.72 & 7.23 & 6.25 \\
$\%$ Nem & 8.20 & 9.8 & 10.5 \\
Demir $\left(\mathrm{mg} \mathrm{Fe} \mathrm{kg}^{-1}\right)$ & 2138 & 27.2 & 0.52 \\
Çinko $\left(\mathrm{mg} \mathrm{Zn} \mathrm{kg}^{-1}\right)$ & 423 & 32.5 & 4,53 \\
Bakır $\left(\mathrm{mg} \mathrm{Cu} \mathrm{kg}^{-1}\right)$ & 33.6 & 11.4 & 0.54 \\
Mangan $\left(\mathrm{mg} \mathrm{Mn} \mathrm{kg}^{-1}\right)$ & 655 & 215 & 0.05 \\
\hline
\end{tabular}

Tarımsal özellikleri ile ilgili ölçüm ve tartımlar (Doğan ve ark., 2015; Doğan ve ark., 2019)'nın kullandıkları yöntemler esas alınmıştır. Deneme sonucunda elde edilen veriler SPSS 22.0 istatiksel analiz programı kullanılarak Bek (1986)'e göre Duncan testi uygulanarak gruplandırılmıştır.

Araştırmada kullanılan besin maddelerinin ekonomik açıdan değerlendirilmesi ve karşılaştırma yapılabilmesi için Cihangir ve Öktem (2016)'in kullandığı şekilde basit ekonomik analiz yapılmıştır. 2015 ve 2016 yıllarındaki verim değerlerinin ortalaması ele alınarak elde edilen değerler Mardin Tarım ve Orman III Müdürlüğünün 2016 yılına ait mısır ürünü maliyet cetvellerinde (TOB, 2016) belirtilen 384.48 TL üretim masrafları (gübreleme masrafları hariç) dikkate alınarak hesaplanmıştır. Elde edilen ürünün satış fiyatı olarak Toprak Mahsulleri Ofisi'nin 2016 yılında mısır ürünü için açıklamış olduğu fiyat olan $740 \mathrm{TL} \mathrm{Ton}^{-1}$ esas alınmıştır (TMO, 2017).

\section{BULGULAR VE TARTIŞMA}

İkinci ürün mısır yetiştiriciliğinde organik ve inorganik gübre uygulamalarının uygulandığı 2015 ve 2016 yıllarında bitkide verim, kalite ve ekonomik analiz sonucu elde edilen karakterler incelenmiştir. Araştırma sonucuna göre yıllar ayrı ayrı ve birleşik değerlendirilmiştir. Deneme yıllarında elde edilen değerler istatistiksel olarak varyans analizine tabii tutularak ortalamalar arasındaki farklılıklar Duncan çoklu karşılaştırma yöntemine göre test edilmiştir.

Çalışma sonucunda çeşitlerin, bitki boyu, ilk koçan yüksekliği, koçan sayısı, koçanda tane sayısı, tek koçan verimi, bin tane ağırlığı ve tane verimi istatiksel olarak \%1 düzeyinde önemli çıkarken hektolitre yağ oranı ve protein oranı ise önemsiz bulunmuştur.

Farklı gübre uygulamaların yağ ve protein oranının dışında incelenen tüm özellikler önemli çıkmıştır. Çeşit gübre interaksiyonunda ise bitki boyu \%1 düzeyinde önemli olurken, koçan uzunluğu, koçanda tane sayısı ve tane verimi \%5 düzeyinde önemli çıkmıştır. İncelenen diğer interaksiyonlar önemsiz bulunmuştur.

Çeşitler içerisinde bitki boyu açısından en yüksek değer birinci yıl $251.3 \mathrm{~cm}$ ile Ç2 çeşidinin G2 uygulamasında elde edilirken, Ç1 çeşidinde ise $243.8 \mathrm{~cm}$ ile G2 uygulamasında elde edilmiştir. En düşük değerler ise her iki çeşidin kontrol parsellerinde elde edilmiştir. İkinci yılda ise en yüksek değer Ç2'de uygulamalarda sırasıyla G3 (242.2 cm), G2 (241.4), G1 (233.2) ve G4 (233.2 cm) takip etmiş ve aynı grupta yer almıştır. Ç1'de ise en yüksek değer G2 uygulamasında $240.8 \mathrm{~cm}$ olarak bitki boyu ölçülürken bunu sırasıyla G3 $(235.9 \mathrm{~cm}), \mathrm{G} 1(232.4 \mathrm{~cm})$ ve G4 $(230.9$ $\mathrm{cm}$ ) uygulamaları takip etmiştir. İki yıl birleştirilmiş ortalamalarda en yüksek değer $246.4 \mathrm{~cm}$ olarak Ç2 çeşidinin G2 uygulamasında, $242.3 \mathrm{~cm}$ ile Ç1 çeşidinin G2 uygulamaları en yüksek boylu bitkiler elde edilirken, en düşük 
bitki boyu ortalama değerleri ise Ç1 ve ç2 kontrol parsellerinde elde edilmiştir. Mısır çeşitlerinin bitki boylarına ilişkin bulgular, bitki boyu daha çok genetik faktörün etkisinde olmakla beraber bölgenin iklim, toprak ve yetiştirme tekniklerine bağlı olarak farklılıkların olabileceğini belirtmiştir (Yılmaz ve Dokuyucu 1994; Doğan ve ark., 2015). Konu ile ilgili yapılan çalışmalarda; Acıbuca (2015), Mardin'de ikinci ürün olarak farklı melez çeşitlerinde bitki boyu ortalamaları $189-227 \mathrm{~cm}$ arasında değiştiğini bildirmiştir. Farklı gübre kaynaklarının uygulanması sonucu olarak, Doğan ve ark., 2019, tavuk gübresi verilen uygulamalarda en yüksek bitki boyuna ulaştı̆̆ını, kontrol parsellerinde en düşük boylu bitkilerin elde edildiğini, diğer taraftan Qasim ve ark., (2001), araştırıcıların bitki boyunun arttığını belirttikleri bulguları ile uyuşmaktadır.

Çizelge 4. İkinci ürün mısır yetiştiriciliğinde farklı gübre uygulamalarının bazı tarımsal özelliklere etkisine ait varyans analiz sonuçları.

Table4. Variance analysis results of the effect of different fertilizer applications on some agricultural properties in 2nd product maize cultivation.

\begin{tabular}{|c|c|c|c|c|c|c|c|c|c|c|}
\hline & $\begin{array}{l}\text { Bitki } \\
\text { Boyu } \\
(\mathrm{cm})\end{array}$ & $\begin{array}{l}\text { Illk Koçan } \\
\text { Yüksekliği } \\
\text { (cm) }\end{array}$ & $\begin{array}{l}\text { Koçan } \\
\text { Uzunluğu } \\
\text { (cm) }\end{array}$ & $\begin{array}{l}\text { Koçanda } \\
\text { Tane } \\
\text { Sayısı } \\
\text { (adet) }\end{array}$ & $\begin{array}{c}\text { Tek } \\
\text { Koçan } \\
\text { Verimi } \\
(\text { gr) }\end{array}$ & $\begin{array}{c}1000 \\
\text { Tane } \\
\text { Ağırlığı } \\
\text { (gr) }\end{array}$ & $\begin{array}{c}\text { Verim } \\
\text { (kg) }\end{array}$ & $\begin{array}{c}\text { Hektolitre } \\
\left(\mathbf{k g ~ h l}^{-1}\right)\end{array}$ & $\begin{array}{l}\text { Yağ } \\
\text { (\%) }\end{array}$ & $\begin{array}{c}\text { Protein } \\
\text { (\%) }\end{array}$ \\
\hline Çeşit & ** & ** & ** & * & $\star *$ & $* \star$ & ** & & & \\
\hline $\begin{array}{l}\text { Gübre Uygulaması } \\
\text { Yıl }\end{array}$ & $\star *$ & ** & ** & ** & ** & ** & ** & & & \\
\hline 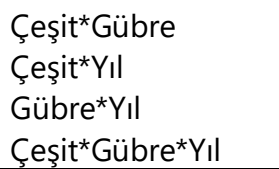 & $* *$ & & * & * & & & * & & & \\
\hline
\end{tabular}

İlk koçan yüksekliği, birinci yıl en düşük değerler her iki çeşidin kontrol parsellerinde elde edilirken, en yüksek koçan yüksekliği ise ç2 çeşidinde sırasıyla G2 $(95.2 \mathrm{~cm}), \mathrm{G} 3(95.1 \mathrm{~cm})$ ve $\mathrm{G} 4(94.7 \mathrm{~cm})$ olarak ölçülürken aynı grupta yer almışlardır. Ç1 çeşidinde ise en yüksek ilk koçan yüksekliği $91.8 \mathrm{~cm}$ ile $\mathrm{G} 1$ uygulamasında ve $91.6 \mathrm{~cm}$ ile G2 uygulamasında elde edilerek aynı grupta yer almıştır. İkinci yıl da ise Ç1 çeşidinde $93.7 \mathrm{~cm}$ ile G1 uygulamasında elde edilmiştir. Ç2 çeşidinde ise sırasıyla koçan yüksekliği $93.9 \mathrm{~cm}$ ile G3, $91.4 \mathrm{~cm}$ G2 ve $90.8 \mathrm{~cm}$ ile G1 uygulaması takip etmiş aynı grupta yer almışlar. Her iki çeşidin ikinci yıl en düşük koçan yüksekliği kontrol parsellerinde elde edilmiştir. İki yıl birleştirilmiş ortalamalarda en yüksek değer $94.4 \mathrm{~cm}$ olarak Ç2 çeşidinin G3 uygulamasında, bunu G2 ve G1 uygulamaları takip ederken, $92.8 \mathrm{~cm}$ ile Ç1 çeşidinin G1 ve $91.2 \mathrm{~cm}$ ile G2 uygulamaları ilk koçan yüksekliği bakımından yüksek olmuştur. En düşük ilk koçan yüksekliği ortalama değerleri ise Ç1 ve Ç2 kontrol parsellerinde elde edilmiştir. Konu ile ilgili yapılan araştırmalarda Öner ve ark. (2011), ilk koçan yüksekliği 92.0-135.0 cm arasında olduğunu, Özata ve ark., (2013), ilk kocan yüksekliği 109.2-145.0 cm olduğu bildirmiştir. Farklı gübre kaynaklarının uygulaması sonucu olarak ilk koçan yüksekliği gübre verilmeyen kontrol parsellerinde, en yüksek ilk koçan uzunluğu ise kimyasal gübre, tavuk gübresi ve çiftlik gübresi verilen parselde elde edildiğini bildirmişlerdir (Doğan ve ark.,2019). Araştırmacının bulguları ile uyum göstermektedir.

Koçan uzunluğu bakımından birinci yıl en düşük değerler her iki çeşidin kontrol parsellerinde elde edilirken, en yüksek koçan yüksekliği ise ç2 çeşidinin G4 $(21.4 \mathrm{~cm})$ elde edilirken, sırasıyla G1 $(20.2 \mathrm{~cm}), \mathrm{G} 2(20.2 \mathrm{~cm})$ ve G3 $(19.6 \mathrm{~cm})$ olarak ölçülürken aynı grupta yer almışlardır. Ç1 çeşidinde ise en yüksek ilk koçan yüksekliği $19.4 \mathrm{~cm}$ ile G1 uygulamasında, bunu da sırasıyla G2 $(19.0 \mathrm{~cm})$ ve G3 $(18.5 \mathrm{~cm})$ uygulamasında elde edilerek aynı grupta yer almıştır. İkinci yılda ise Ç2 çeşidinde $21.1 \mathrm{~cm}$ ile G2 uygulamasında bunu da sırasıyla, G1, G4 ve G3 uygulaması takip etmiş ve aynı grupta yer almıştır. Ç2 çeşidinde ise $19.1 \mathrm{~cm}$ ile G2 uygulaması ile elde edilirken bunu G1 uygulaması takip etmiştir. Her iki çeşidin ikinci yıl en düşük koçan uzunluğu kontrol parsellerinde elde edilmiştir. İki yıl birleştirilmiş ortalamalarda en yüksek değer $20.7 \mathrm{~cm}$ olarak Ç2 çeşidinin G2 ve G4 uygulamasında, bunu G1 ve G3 uygulamaları takip ederken, $19.6 \mathrm{~cm}$ ile Ç1 çeşidinin $\mathrm{G} 1$ uygulaması bunu da $\mathrm{G} 2$ ve $\mathrm{G} 3$ takip etmiş ve aynı grupta yer almışlardır. En düşük koçan uzunluğu ortalama değerleri ise Ç1 ve Ç2 kontrol parsellerinde elde edilmiştir. Koçan uzunluğu bitkinin çeşit özelliği yanında ekim zamanı, toprak ve çevre koşullarına bağlı olarak değişiklik gösterebilmektedir. Bitkide koçanın uzun olması istenilir. Koçan boyu artınca tane veriminde artış olur. Koçan uzunluğu ile ilgili farklı ekolojilerde yapılan çalışmalarda; Özata ve Kapar 2013, 17.1-26.3 cm arasında, Konuşkan ve ark. 2015 ise 17.6-19.2 cm arasında tespit etmişlerdir. Farklı gübre kaynaklarının uygulaması sonucu olarak koçan uzunluğu 17.7-20.3 cm arsında değiştiğini en düşük değerin kontrol parsellerinde, en yüksek koçan 
uzunluğu ise tavuk gübresinin verildiği parselde elde ederken bunu kimyasal gübre ve çiftlik gübresi verilen parsellerin takip ettiğini bildirmişlerdir (Doğan ve ark., 2019). Araştırmacının bulguları ile uyum göstermektedir.

Koçanda tane sayısı bakımından birinci yıl en düşük değerler her iki çeşidin kontrol parsellerinde elde edilirken, en yüksek koçanda tane sayısı Ç2 çeşidinin G1 (526.4 adet) elde edilirken, bunu G2 (512.0 adet) uygulaması takip etmiş ve aynı grupta yer almışlardır. Ç1 çeşidinde ise en yüksek koçanda tane sayısı 513.7 adet ile G1 uygulamasında elde edilmiştir. Ikinci yılda ise ç2 çeşidinde 501.8 adet G2 uygulamasında, Ç1 çeşidinde ise 500.0 adet ile G1 uygulaması ile elde edilmiştir. Her iki çeşidin ikinci yıl en düşük koçan uzunluğu kontrol parsellerinde elde edilmiştir. İki yıl birleştirilmiş ortalamalarda en yüksek değer 506.9 adet ile Ç1 ve ç2 çeşitlerin G1 uygulamasında elde edilirken bunu Ç2'nin G1 (505.8 adet) uygulaması takip ederken, $469.4 \mathrm{~cm}$ ile Ç2 çeşidinin G3 uygulaması takip etmiş ve aynı gurupta yer almışlardır. En düşük koçan uzunluğu ortalama değerleri ise Ç1 ve Ç2 kontrol parsellerinde elde edilmiştir. Konu ile ilgili olarak farklı ekolojik koşullarında yapılan çalışma sonuçlarına göre çeşitlerin koçan sayısı bakımında önemli farklııkların olduğunu Demir 2016, yapılan çalışmasında 585.0-627.2 adet arasında olduğunu, Akan 2017, mısır çeşitlerin 497.7-736.7 arasında değiştiğini, Gür 2019, çalışmada ise 470.3-881.3 g arasında değiştiği bildirmişlerdir. Araştırmacıların koçanda dane sayısı açısından elde ettikleri sonuçlar araştırmamızdaki bulgularımızla uyum göstermektedir. Khaliq (2004)'de yaptığı çalışmada azotlu gübre+sığır gübresinin verildiği parsellerde, sadece ticari gübre verilen parsellere elde edilen koçan sayısı diğer uygulamalara (tavuk gübresi ve ticari gübre) göre daha yüksek değer elde ettiğini bildirirken, Uzun ve ark. (2005)'nın verim öğelerinden olan koçanda tane sayısı farklı uygulamalar sonucunda etkilenebileceğini bildirmiştir. Bu çalışma sonuçları bulgularımızla kısmen uymaktadır.

Bitkide tek koçan verimi özelliği yönünden, birinci yıl en düşük değerler her iki çeşidin kontrol parsellerinde elde edilirken, en yüksek bitkide koçan verimi Ç2 çeşidinin G1 (36.9 g) elde edilirken, Ç1 çeşidinde ise en yüksek tek koçan verimi $33.3 \mathrm{~g}$ ile G1 uygulamasında elde edilmiştir. İkinci yıl da ise Ç2 çeşidinde $35.7 \mathrm{~g} \mathrm{G1}$ uygulamasında, Ç1 çeşidinde ise $32.2 \mathrm{~g}$ ile G1 uygulaması ile elde edilmiş ve G2 (31.3 g) uygulaması ile aynı gurupta yer almıştır. Her iki çeşidin ikinci yıl en düşük tek koçan verimi kontrol parsellerinde elde edilmiştir. i̇ki yıl birleştirilmiş ortalamalarda en yüksek değer $36.3 \mathrm{~g}$ ile Ç1'nin G1 uygulamasında bunu da sırasıyla G3 ve G4 uygulaması takip etmiş aralarındaki fark önemsiz çıkmıştır. Ç1 çeşidinde ise $32.8 \mathrm{~g}$ ile G1 uygulamasında elde edilirken, G2 ile aynı grupta yer almışlardır. En düşük ortalama değerleri ise Ç1 ve Ç2 kontrol parsellerinde elde edilmiştir. (Difonzo ve ark. 1982; Türkay ve ark. 2002; Celep 2006)'nın tek koçan verimi yönünden çeşitler arasında farklıık olduğunu belirttikleri bulguları, bulgularımızı desteklemektedir. Farklı gübre kaynaklarının uygulaması sonucunda koçan verimi 24.4-38.7 adet arsında değiştiğini en düşük değerin kontrol parsellerinde, en yüksek tek koçan verimini ise sırasıyla ticari gübre, tavuk gübresi ve çiftlik gübresi verilen parsellerin takip ettiğini bildirmişlerdir (Doğan ve ark.,2019). Araştırmacının bulguları ile uyum göstermektedir.

Bin tane ağırlığı yönünden çeşitler arasındaki fark incelendiğinde birinci ve ikinci yılda en düşük değerler her iki çeşidin kontrol parsellerinde elde edilirken, en yüksek bin tane ağırlığı $153.5 \mathrm{~g}$ ile ç2 çeşidinin G1 uygulamasında elde edilmiş, Ç1 çeşidinde ise en yüksek $150.2 \mathrm{~g}$ ile G1 uygulamasında elde edilmiştir. İkinci yıl da ise Ç2 çeşidinde $148.2 \mathrm{~g} \mathrm{G1}$ uygulamasında, Ç1 çeşidinde ise $146.9 \mathrm{~g}$ ile G1 uygulaması ile elde edilmiştir. Her iki çeşidin ikinci yıl en düşük bin tane ağırlığı kontrol parsellerinde elde edilmiştir. İki yıl birleştirilmiş ortalamalarda en yüksek bin tane ağırlı̆ı $150.8 \mathrm{~g}$ ile Ç1'nin G1 uygulamasında bunu da sırasıyla G2 ve G3 uygulaması takip etmiş aralarındaki fark önemsiz çıkmışırı. Ç1 çeşidinde ise $148.6 \mathrm{~g}$ ile G1 uygulamasında elde edilmiş, en düşük ortalama değerleri ise Ç1 ve Ç2 kontrol parsellerinde elde edilmiştir. Sezer ve Gülümser (1999), Türkay ve ark. (2002), bin tane ağırlığının çeşit ve çevre şartlarına göre önemli farklıık gösterdiğini belirtmişlerdir. Bu tespitler, bulgularımızla uyuşmaktadır. Farklı gübre kaynaklarının uygulaması sonucunda en düşük değerin kontrol parsellerinde, en yüksek bin tane ağırlığını ise yıllara göre değişmekle beraber sırasıyla çiftlik gübresi, tavuk gübresi ve ticari gübre uygulamalarında elde edildiğini ve aralarındaki farkın önemli olmadığını bildirmişlerdir (Doğan ve ark.,2019). Araştırmacının bulguları ile uyum göstermektedir.

Tane verimi özelliği yönünden çeşitler arasındaki fark incelendiğinde birinci ve ikinci yılda en düşük değerler her iki çeşidin kontrol parsellerinde elde edilmiştir. Birinci yılda en yüksek tane verimi $1235.2 \mathrm{~kg} \mathrm{da}^{-1}$ ile Ç1 çeşidinin G1 uygulamasında elde edilirken, ikinci sırada $1175.3 \mathrm{~kg} \mathrm{da}^{-1}$ ile Ç2'nin G1 uygulamasında elde edilirken bunu sırasıyla, G2 $\left(1099.5 \mathrm{~kg} \mathrm{da}^{-1}\right), \mathrm{G} 3\left(1080.6 \mathrm{~kg} \mathrm{da}^{-1}\right)$ ve G4 (1074.1 $\left.\mathrm{kg} \mathrm{da}^{-1}\right)$ uygulaması takip etmiş aralarındaki fark önemsiz çıkmıştır. İkinci yılda ise Ç1 çeşidinde $1203.2 \mathrm{~kg} \mathrm{da}^{-1} \mathrm{G} 1$ uygulamasında, Ç2 çeşidinde ise $1149.3 \mathrm{~kg}$ $\mathrm{da}^{-1}$ ile $\mathrm{G} 2$ uygulaması ile elde edilmiş kontrol parselleri dışındaki uygulamalar ile aynı grupta yer almıştır. İki yıl birleştirilmiş ortalamalarda en yüksek tane verimi $1219.2 \mathrm{~kg} \mathrm{da}^{-1}$ ile Ç1'in G1 uygulamasında, Ç2 çeşidinde ise 1124.4 ile G2 uygulamasında elde edilmiş, bunu sırasıyla G3, G1 ve G4 uygulamaları takip etmiştir. Tane verimi ile ilgili olarak elde edilen sonuçların birbirinden farkıı olması çalışmalarda kullanılan çeşidin genetik yapısı, toprak, 
iklim ve yetiştirme teknikleri bakımından kaynaklandığı söylenebilir. Konu ile ilgili olarak; Çakır 1996, tane verimini 925.5-1502 kg da ${ }^{-1}$, Konuşkan ve ark. (2015), 1378-1218 kg da ${ }^{-1}$ arasında tespit etmiştir. Acıbuca, (2015), Mardin'de ikinci ürün olarak farklı melez çeşitlerinde tane verimi ortalamaları $831.0-1120.0 \mathrm{~kg} \mathrm{da}^{-1} \mathrm{arasında}$ değiştiğini bildirmişlerdir. Farklı gübre kaynaklarının uygulanması ile ilgi araştırmalara göre; Morris ve Lathwell 2004; Dordas ve ark., 2008; Efthimiadou ve ark., 2010) tane verimi sığır gübresinden; Khan ve ark., 2008; Bamire ve Amujoyegbe 2004) tavuk gübresinden; Mitchell ve Tu (2005) tavuk gübresi + inorganik gübreden; Prasanna ve ark. (2007) solucan gübresinden; Ashoka ve ark. (2009) solucan gübre + kimyasal gübresinde; Doğan ve ark., 2019 en düşük tane verimini kontrol parsellerinde en yüksek tane verimini ise yıllara göre farklılık göstermiş olup tavuk gübresi, ticari gübre ve çiftlik gübresinin uygulanmasında elde edildiği bildirmişlerdir. Buna göre farklı mısır çeşitlerinin tane verimleri değişiminin genetik faktörlerin yanında faklı uygulama yöntemlerinden kaynaklandığı ve bunun beklenen bir sonuç olduğu söylenebilir. Bu bulgular da bizim bulgularımızı desteklemektedir. Diğer taraftan; Neil ve.Kevin (2001), mısırda gübresiz, kimyasal gübre, çiftlik ve tavuk gübresinin uygulandığı çalışmada en düşük tane verimini kontrol parselinde elde ederken, çiftlik gübresi uygulanan parsellerden tane verimi yönünden daha iyi sonuç aldıklarını bildirirken, Warman ve Havard (1998), kimyasal ve organik gübrelerin mısırda tane verimine etkisini incelemiş, 3 yıllık çalışma sonucu organik, kimyasal gübre uygulamasından daha yüksek verim elde edilmiştir.

Çizelge 5. İkinci ürün mısır yetiştiriciliğinde organik ve inorganik gübre uygulamalarııın verim ve kalite öğeleri üzerine etkisi Table 5. The effect of organic and inorganic fertilizer applications on yield and quality elements in 2nd product crop cultivation*.

\begin{tabular}{|c|c|c|c|c|c|c|c|}
\hline Çeşit & Gübre & YII & $\begin{array}{l}\text { Bitki boyu } \\
(\mathrm{cm})\end{array}$ & $\begin{array}{c}\text { ilk koçan } \\
\text { yüksekliği } \\
\text { (cm) }\end{array}$ & $\begin{array}{l}\text { Koçan } \\
\text { uzunluğu } \\
(\mathbf{c m})\end{array}$ & $\begin{array}{l}\text { Koçan tane } \\
\text { sayısı (adet) }\end{array}$ & $\begin{array}{c}\text { Tek koçan } \\
\text { verimi }(\mathbf{k g})\end{array}$ \\
\hline \multirow{15}{*}{ Ç1 } & \multirow{3}{*}{ G0 } & 1.YII & $191.2 \mathrm{c}$ & $75.8 c$ & $15.6 b$ & $411.8 c$ & $23.8 c$ \\
\hline & & 2.YII & $192.0 \mathrm{~b}$ & $75.1 c$ & $15.8 c$ & $413.3 c$ & $24.8 b$ \\
\hline & & Ortalama & $191.6 c$ & $75.4 \mathrm{c}$ & $15.7 c$ & $412.6 c$ & $24.3 b$ \\
\hline & \multirow{3}{*}{ G1 } & $1 . Y_{I}$ & $235.4 a b$ & $91.8 a$ & $19.4 a$ & 513.7a & $33.3 a$ \\
\hline & & 2.YII & $232.4 a$ & $93.7 a$ & $19.8 a$ & $500.0 \mathrm{a}$ & $32.2 a$ \\
\hline & & Ortalama & 233.9ab & $92.8 a$ & $19.6 a$ & $506.9 a$ & $32.8 a$ \\
\hline & \multirow{3}{*}{ G2 } & $1 . Y_{I}$ & $243.8 a$ & $91.6 a$ & $19.0 a$ & $455.0 \mathrm{~b}$ & 31.2ab \\
\hline & & 2.YII & $240.8 a$ & $90.7 \mathrm{ab}$ & $19.1 \mathrm{a}$ & $447.6 b$ & 31.3a \\
\hline & & Ortalama & $242.3 a$ & $91.2 \mathrm{a}$ & $19.1 \mathrm{a}$ & $451.3 b$ & $31.3 a$ \\
\hline & \multirow{3}{*}{ G3 } & $1 . Y_{I}$ & 237.3ab & 91.0ab & $18.5 a$ & $440.0 \mathrm{bc}$ & $27.4 b c$ \\
\hline & & 2.YII & $235.9 a$ & $89.4 a b$ & 18.7ab & $435.1 b c$ & 28.0ab \\
\hline & & Ortalama & 236.6ab & $90.2 a b$ & $18.6 a$ & 437.6 b & $27.7 b$ \\
\hline & \multirow{3}{*}{ G4 } & $1 . Y_{I}$ & $229.7 b$ & $85.9 b$ & $16.9 b$ & $432.0 \mathrm{bc}$ & $25.9 c$ \\
\hline & & 2.YII & $230.9 a$ & $86.8 b$ & $17.1 b c$ & $428.7 b c$ & $26.0 \mathrm{~b}$ \\
\hline & & Ortalama & $230.3 b$ & $86.4 b$ & $17.0 \mathrm{~b}$ & $430.4 b c$ & $25.9 b$ \\
\hline \multicolumn{3}{|c|}{ CV (\%) } & 8.51 & 7.79 & 9.09 & 7.99 & 13.49 \\
\hline \multirow{16}{*}{ Ç2 } & \multirow{4}{*}{ G0 } & $1 . Y_{I}$ & $226.3 c$ & $86.0 \mathrm{~b}$ & $16.8 \mathrm{~b}$ & $415.4 b$ & $28.9 b$ \\
\hline & & 2.YII & $221.9 b$ & $84.8 b$ & $17.2 \mathrm{~b}$ & $420.9 b$ & $29.9 b$ \\
\hline & & Ortalama & $224.1 c$ & $85.4 b$ & $17.0 \mathrm{~b}$ & $418.2 c$ & $29.4 b$ \\
\hline & & $1 . Y_{I}$ & $245.8 a b$ & $95.2 a$ & $20.2 a$ & $526.4 a$ & $36.9 a$ \\
\hline & \multirow[t]{3}{*}{ G1 } & 2.YII & $239.3 a$ & $90.8 a$ & $20.5 a$ & 485.3ab & $35.7 a$ \\
\hline & & Ortalama & $242.5 a b$ & $93.0 a$ & $20.3 a$ & $505.8 a$ & $36.3 a$ \\
\hline & & $1 . Y_{I}$ & $251.3 a$ & $95.6 a$ & $20.2 a$ & $512.0 \mathrm{a}$ & $33.4 a b$ \\
\hline & \multirow[t]{3}{*}{ G2 } & 2.YII & $241.4 a$ & $91.4 a$ & $21.1 a$ & $501.8 a$ & $33.3 a b$ \\
\hline & & Ortalama & $246.4 a$ & $93.5 a$ & $20.7 a$ & $506.9 a$ & $33.4 a$ \\
\hline & & $1 . Y_{I}$ & $244.5 a b$ & $94.7 a$ & $19.6 a$ & 472.7ab & $34.5 a b$ \\
\hline & \multirow[t]{3}{*}{ G3 } & $2 . Y_{I}$ & $242.2 \mathrm{a}$ & $93.9 a$ & $19.4 a$ & $466.2 \mathrm{ab}$ & 34.0ab \\
\hline & & Ortalama & $243.4 a b$ & $94.4 a$ & $19.5 a$ & 469.4ab & $34.4 a$ \\
\hline & & $1 . Y_{I}$ & $238.5 b$ & $89.2 a b$ & $21.4 a$ & 427.7b & $33.5 a b$ \\
\hline & \multirow[t]{2}{*}{ G4 } & 2.Yll & $233.2 \mathrm{ab}$ & 88.9ab & $20.0 a$ & $421.7 b$ & $32.4 a b$ \\
\hline & & Ortalama & $235.9 b$ & $89.0 \mathrm{ab}$ & $20.7 a$ & $424.7 \mathrm{bc}$ & $32.9 \mathrm{ab}$ \\
\hline & \multicolumn{2}{|c|}{ CV (\%) } & 4.28 & 6.31 & 9.89 & 10.27 & 9.95 \\
\hline
\end{tabular}

*Aynı sütunda aynı harfle gösterilen ortalamalar arasındaki farklar önemsizdir. 
Çizelge 6. İkinci ürün mısır yetiştiriciliğinde organik ve inorganik gübre uygulamalarının verim ve kalite öğeleri üzerine etkisi. Table6. The effect of the organic and inorganic fertilizer applications on yield and quality elements in 2nd product crop cultivation*.

\begin{tabular}{|c|c|c|c|c|c|c|c|}
\hline Çeşit & Gübre & YII & $\begin{array}{c}1000 \text { tane } \\
\text { ağırlığı (gr) }\end{array}$ & $\begin{array}{c}\text { Tane verimi } \\
(\mathbf{k g})\end{array}$ & $\begin{array}{c}\text { Hektolitre } \\
\left(\mathrm{kg} \mathrm{hl}^{-1}\right)\end{array}$ & Yağ (\%) & Protein (\%) \\
\hline \multirow{16}{*}{ Ç1 } & \multirow{4}{*}{ G0 } & 1.YII & $131.2 \mathrm{c}$ & $615.6 c$ & $70.1 a$ & $3.7 a$ & $9.2 \mathrm{a}$ \\
\hline & & 2.YII & $133.5 \mathrm{c}$ & $634.0 c$ & $71.1 \mathrm{a}$ & $3.9 a$ & $9.3 a$ \\
\hline & & Ortalama & $132.4 \mathrm{c}$ & $624.8 c$ & $70.6 a b$ & $3.8 \mathrm{a}$ & $9.3 a$ \\
\hline & & $1 . Y_{I}$ & $150.2 a$ & $1235.2 a$ & $74.0 \mathrm{a}$ & $3.8 \mathrm{a}$ & $9.5 a$ \\
\hline & \multirow[t]{3}{*}{ G1 } & 2.YII & $146.9 a$ & $1203.2 a$ & $73.7 a$ & $3.9 a$ & $9.6 a$ \\
\hline & & Ortalama & $148.6 a$ & $1219.2 a$ & $73.8 a$ & $3.9 a$ & $9.5 a$ \\
\hline & & $1 . Y_{l}$ & $138.9 b c$ & $1055.3 b$ & $69.9 a$ & $3.5 a$ & $9.2 \mathrm{a}$ \\
\hline & \multirow[t]{3}{*}{ G2 } & 2.YII & $140.5 a-c$ & $1064.2 b$ & $69.9 a$ & $3.9 a$ & $8.6 a$ \\
\hline & & Ortalama & $139.7 \mathrm{~b}$ & $1059.8 b$ & $69.9 \mathrm{~b}$ & $3.7 a$ & $8.9 a$ \\
\hline & & $1 . Y_{I}$ & 144.0ab & $1036.5 b$ & $69.9 a$ & $3.8 \mathrm{a}$ & $9.6 a$ \\
\hline & \multirow[t]{3}{*}{ G3 } & $2 . Y_{I}$ & $139.5 b c$ & $1033.9 b$ & $71.7 a$ & $4.1 \mathrm{a}$ & $9.4 a$ \\
\hline & & Ortalama & $141.8 b$ & $1035.2 b$ & $70.8 \mathrm{ab}$ & $3.9 a$ & $9.5 a$ \\
\hline & & $1 . Y_{I}$ & 143.9ab & $1000.3 b$ & $72.2 a$ & $3.6 a$ & $9.3 a$ \\
\hline & \multirow[t]{2}{*}{ G4 } & $2 . Y_{I I}$ & 141.9ab & $1018.6 b$ & $72.6 a$ & $3.9 a$ & $9.7 a$ \\
\hline & & Ortalama & 142.9ab & $1009.5 b$ & $72.4 \mathrm{ab}$ & $3.7 a$ & $9.5 a$ \\
\hline & \multicolumn{2}{|c|}{ CV (\%) } & 4.59 & 21.07 & 3.47 & 9.97 & 8.14 \\
\hline \multirow{16}{*}{ Ç2 } & \multirow{4}{*}{ G0 } & 1.YII & $137.9 \mathrm{~b}$ & $637.6 b$ & $67.9 a$ & $4.3 a$ & $9.6 a$ \\
\hline & & $2 . Y_{I}$ & $139.1 b$ & $685.9 \mathrm{~b}$ & $69.7 a$ & 4.3a & $9.8 a$ \\
\hline & & Ortalama & $138.5 b$ & $661.7 b$ & $68.8 a$ & $4.3 a$ & $9.7 a$ \\
\hline & & $1 . Y_{l}$ & $153.5 a$ & $1175.3 a$ & $73.8 a$ & $4.3 a$ & $10.1 a$ \\
\hline & \multirow[t]{3}{*}{ G1 } & 2.YII & $148.2 a$ & $980.6 a$ & $71.8 a$ & $4.6 a$ & $9.6 a$ \\
\hline & & Ortalama & $150.8 a$ & $1078.0 a$ & $72.8 a$ & $4.5 \mathrm{a}$ & $9.9 a$ \\
\hline & & $1 . Y_{I}$ & 149.1ab & $1099.5 a$ & $70.9 a$ & $4.2 \mathrm{a}$ & $9.9 a$ \\
\hline & \multirow[t]{3}{*}{ G2 } & $2 . Y_{I}$ & $145.7 a$ & $1149.3 a$ & $71.7 a$ & $4.6 a$ & $10.3 a$ \\
\hline & & Ortalama & $147.4 \mathrm{a}$ & $1124.4 a$ & $71.3 a$ & $4.4 a$ & $10.2 a$ \\
\hline & & $1 . Y_{I}$ & 147.6ab & $1080.6 a$ & $71.2 \mathrm{a}$ & $4.4 a$ & $9.8 a$ \\
\hline & \multirow[t]{3}{*}{ G3 } & $2 . Y_{I}$ & $143.1 \mathrm{a}$ & $1080.4 a$ & $72.6 a$ & $4.2 \mathrm{a}$ & $9.7 a$ \\
\hline & & Ortalama & $145.4 a b$ & $1080.5 a$ & $71.9 a$ & $4.3 a$ & $9.8 a$ \\
\hline & & $1 . Y_{I}$ & 146.6ab & $1074.1 \mathrm{a}$ & $69.7 a$ & $4.4 a$ & $10.7 a$ \\
\hline & \multirow[t]{2}{*}{ G4 } & 2.YII & $144.4 \mathrm{a}$ & 1066.3a & $70.0 a$ & $4.1 \mathrm{a}$ & $10.4 a$ \\
\hline & & Ortalama & $145.5 \mathrm{ab}$ & $1070.2 a$ & $69.9 a$ & $4.2 \mathrm{a}$ & $10.5 a$ \\
\hline & \multicolumn{2}{|c|}{ CV (\%) } & 4.38 & 20.00 & 4.03 & 8.83 & 7.95 \\
\hline
\end{tabular}

*Aynı sütunda aynı harfle gösterilen ortalamalar arasındaki farklar önemsizdir.

Hektolitre yönünden çeşitler ve uygulamalar arasındaki fark incelendiğinde birinci ve ikinci yılda ve iki yıl birleştirilmiş ortalamalarda çeşit ve uygulanan gübre kaynakları arasındaki farklılıklar istatiksel olarak önemsiz olmuştur. Akan, (2017), farklı mısır çeşitlerinde yaptıkları çalışmada hektolitre özelliğinin çeşitler özerinde etkisinin önemsiz olduğunu belirtirken, diğer taraftan Elmalı ve Soylu (2008) ile paralellik arz ederken, (Özmen 2008) hektolitre ağırlığında genotip $x$ çevre interaksiyonunun önemli olduğunu bildirmiştir. Bu durumun araştırmanın yürütüldüğü yıl, çevre şartları ve materyal farklılı̆ıından kaynaklanmış olabileceği düşünülmektedir.

Yağ oranı bakımında çeşitler ve uygulamalar arasındaki fark incelendiğinde birinci ve ikinci yılda ve iki yıl birleştirilmiş ortalamalarda çeşit ve uygulanan gübre kaynakları arasındaki farklılıklar istatiksel olarak önemsiz bulunmuştur. Cengiz ve ark. (2010), sentetik ve organik gübre kaynaklarının uygulandığı mısır çeşitlerinde hektolitre ürerinde etkisinin önemsiz olduğunu bildirmişlerdir.

Protein oranı bakımından çeşitler ve uygulamalar arasındaki fark incelendiğinde birinci ve ikinci yılda ve iki yıl birleştirilmiş ortalamalarda çeşit ve uygulanan gübre kaynakları istatiksel olarak önemsiz olmuştur. Mısır çeşitleri ile yapmış oldukları çalışmada protein oranı önemsiz olduğunu; Kalkan, (2008) \%4.33-4.51; Koca, (2009) \% 4.284.73; nın bulguları ile paralellik gösterirken, Cengiz ve ark., (2010), sentetik ve organik gübre kaynaklarının uygulandığı mısır çeşitlerinde hektolitre ürerinde etkisinin önemsiz olduğunu bildirmişlerdir. Yaptığımız 
çalışmada tane kalite analizlerinde, organik gübrelerin mısır tanesinde bulunan protein, yağ ve nişasta miktarlarını olumsuz etkilemediği görülmüştür.

\section{Ekonomik Analiz}

Araştırmada kullanılan gübrelerin 2016 yılı serbest piyasa fiyatları ve kullanılan miktarları çizelge 7'de verilmiştir.

Çizelge 7. Çalışmada kullanılan besin maddelerinin miktar ve fiyatları.

Table7. Quantity and prices of nutrients used in the study.

\begin{tabular}{|c|c|c|}
\hline Besin Maddesi & Fiyat $\left(\mathrm{TL} \mathrm{kg}^{-1}\right)^{*}$ & Kullanılan Miktar $\left(\mathrm{kg} \mathrm{da}^{-1}\right)$ \\
\hline Çiftlik Gübresi & 0.09 & 1500 \\
\hline Tavuk Gübresi & 0.13 & 1000 \\
\hline Solucan Gübresi & 1.50 & 1200 \\
\hline AN \% 33 & 1.05 & 60.6 \\
\hline TSP \% 42 & 1.00 & 19.0 \\
\hline
\end{tabular}

*2016 yllı serbest piyasa fiyatlarıdır.

Çizelge 8'de Ç1 çeşidi için yapılan analizde kârlıık bakımından birinci sırada (G2) konvansiyonel gübrenin $\left(442.91 \mathrm{TL} \mathrm{da}^{-1}\right)$ geldiği tespit edilmiştir. Daha sonra sırasıyla tavuk gübresi (285.46 TL da-1) ve çiftlik gübresi (246.42 $\mathrm{TL} \mathrm{da}^{-1}$ ) gelmektedir. Solucan gübresinin piyasa fiyatlarının kullanılan diğer gübrelere göre oldukça yüksek olması ve elde edilen verim miktarının da düşük olması yapılan uygulamadan zarar edilmesine $\left(-1437.82 \mathrm{TL} \mathrm{da}^{-1}\right)$ neden olmuştur.

Çizelge 8. Ç1 çeşidi için kullanılan gübrelerin ekonomik karlıık analizi.

Table 8. Economic profitability analysis of fertilizers used for Ç1 variety.

\begin{tabular}{|c|c|c|c|c|c|c|}
\hline $\begin{array}{l}\text { Gübre } \\
\text { Çeşidi }\end{array}$ & $\begin{array}{c}\text { Ortalama } \\
\text { Verim } \\
\left(\mathrm{kg} \mathrm{da}^{-1}\right)\end{array}$ & $\begin{array}{c}\text { Genel } \\
\text { Masraflar } \\
\left(\text { TL da }^{-1}\right)\end{array}$ & $\begin{array}{l}\text { Gübre } \\
\text { Masrafi } \\
\left(\text { TL da }^{-1}\right)\end{array}$ & $\begin{array}{l}\text { Toplam } \\
\text { Masraf } \\
\left(\text { TL da }^{-1}\right)\end{array}$ & $\begin{array}{l}\text { GSÜD } \\
\left(\text { TL da }^{-1}\right)\end{array}$ & $\begin{array}{l}\text { Kârlılık } \\
\left(T^{\prime} \text { da }^{-1}\right)\end{array}$ \\
\hline G1 & 618 & 384.48 & 0.00 & 384.48 & 457.32 & 72.84 \\
\hline G2 & 1223 & 384.48 & 82.63 & 467.11 & 905.02 & 437.91 \\
\hline G3 & 1081 & 384.48 & 130.00 & 514.48 & 799.94 & 285.46 \\
\hline G4 & 1035 & 384.48 & 135.00 & 519.48 & 765.90 & 246.42 \\
\hline G5 & 1009 & 384.48 & 1800.00 & 2184.48 & 746.66 & -1437.82 \\
\hline
\end{tabular}

Ç2 çeşidi için yapılan karlıık analizinde de çalışmada kullanılan konvansiyonel gübrenin kârlıık değerinin birinci sırada (394.99 $\mathrm{TL} \mathrm{da}^{-1}$ ), tavuk gübresinin ikinci sırada (317.28 TL da ${ }^{-1}$ ) ve çiftlik gübresinin üçüncü sırada (279.72 $\mathrm{TL} \mathrm{da}^{-1}$ ) yer aldığı, uygulamada kullanılan solucan gübresinin ise $1392.68 \mathrm{TL}_{\mathrm{da}}{ }^{-1}$ zarara neden olduğu tespit edilmiştir. Erkoyuncu (2008), Acar ve ark. (2009) ile Cihangir ve Öktem (2016)'in yaptıkları çalışmalarda da organik üretimle üretilen ürünlerin maliyetinin daha yüksek olduğu sonucuna varılmıştır.

Çizelge 9. Ç2 çeşidi için kullanılan gübrelerin ekonomik karlılık analizi.

Table 9. Economic profitability analysis of fertilizers used for Ç2 variety.

\begin{tabular}{|c|c|c|c|c|c|c|}
\hline $\begin{array}{l}\text { Gübre } \\
\text { Çeşidi }\end{array}$ & $\begin{array}{c}\text { Ortalama } \\
\text { Verim } \\
\left(\mathrm{kg} \mathrm{da}^{-1}\right)\end{array}$ & $\begin{array}{c}\text { Genel } \\
\text { Masraflar } \\
\left(\text { TL da }^{-1}\right)\end{array}$ & $\begin{array}{c}\text { Gübre } \\
\text { Masrafı } \\
\left(\text { TL da }^{-1}\right)\end{array}$ & $\begin{array}{c}\text { Toplam } \\
\text { Masraf } \\
\left(\mathrm{TL} \mathrm{da}^{-1}\right)\end{array}$ & $\begin{array}{c}\text { GSÜD } \\
\left(T^{\prime} \text { da }^{-1}\right)\end{array}$ & $\begin{array}{c}\text { Kârlılık } \\
\left(T^{\prime} \text { da }^{-1}\right)\end{array}$ \\
\hline G1 & 662 & 384.48 & 0.00 & 384.48 & 489.88 & 105.40 \\
\hline G2 & 1165 & 384.48 & 82.63 & 467.11 & 862.10 & 394.99 \\
\hline G3 & 1124 & 384.48 & 130.00 & 514.48 & 831.76 & 317.28 \\
\hline G4 & 1080 & 384.48 & 135.00 & 519.48 & 799.20 & 279.72 \\
\hline G5 & 1070 & 384.48 & 1800.00 & 2184.48 & 791.80 & -1392.68 \\
\hline
\end{tabular}

\section{SONUÇ}

II. ürün mısır çeşitlerinde organik ve inorganik gübre kaynaklarının uygulandığı çalışma sonucunda verim açısından Ç1 (Dekalb 5401) çeşidi ön plana çıkarken uygulama olarak da G1 (ticari gübre) verilen parsellerde 
ortalama olarak $1219.2 \mathrm{~kg} \mathrm{da}^{-1}$ olarak elde edilmiştir. Organik gübre olarak da en yüksek tane verimi ortalama değer Ç2 (LG 30.597) çeşidinin G2 (tavuk gübresi) uygulamalarında elde edilmiştir. Kalite parametreleri bakımından çeşit ve gübre uygulamaları arasında fark olmadığı tespit edilmiştir. Mısır bitkisi gübreye karşı olumlu tepki veren bir bitki olup özellikle mısırın vejetatif gelişmesi artııça topraktan alacağı azot miktarı da artar. Azot mısır bitkisinin verimini etkileyen bir faktör olup, mısır bitkisinin fazla miktarda azota ihtiyacı vardır. Fazla kullanılan gübre toprağın yapısını bozmaktadır. Bu alternatif olarak organik gübre kullanımını yaygınlaştıılarak çevre üzerindeki olumsuz etkiyi azaltarak toprağın organik madde miktarının arttııılması, toprağın fiziksel, kimyasal ve biyolojik yapısının düzelttirmesi için oldukça önemlidir. Kontrolsüz kullanılan organik gübrenin bazı olumsuzlukları da bulunmaktadır. Hayvan sağlığı için kullanılan antibiyotik ve veteriner ilaçlarının yoğun kullanılması sonucu organik gübre temin edilen çiftliklerde sorun oluşabilmektedir. Tavuk üretimi yapılan çiftliklerin gübrelerinin bünyelerinde Tetracycline, Oxytetracycline ve Chlortetracycline maddeleri yüksek oranda bulunabilmekte, tarımsal üretimde kullanılan bu gübreler ile antibiyotik etken maddeleri toprağa geçebilmektedir. Bu oran Kirlilik Tolerans (PICT) değerlerinin üzerinde çıkması durumunda mikroorganizma üzerinde olumsuz etki yaparak azalmasına veya antibiyotiklere karşı dayanıklı mikroorganizma sayısının artmasına ve toprak mikroflora (Biota) dengesinin bozulmasına neden olabilmektedir. Tavuk gübresi aşırı düzeylerde uygulandığında çeşitli tuzlar toprakta birikebilir ve yetiştirilen bitkilere toksik etkide bulunabilir.

Ekonomik analiz neticesinde çeşitler arasında konvansiyonel gübre uygulamaları bakımından Ç1 (Dekalb 5401) çeşidinin kârlılık düzeyi daha yüksek iken organik gübre uygulamaları açısından yapılan değerlendirmede Ç2 (LG 30.597) çeşidinin daha kârlı olduğu bulunmuştur. Çalışmadan elde edilen sonuçlar geleneksel gübre uygulamalarının düşük maliyetli, elde edilen verim ve dolayısıyla kârılık düzeyinin daha yüksek olduğunu gösterse de, organik üretimle elde edilen mısır ürününün piyasasının oluşmaması nedeniyle konvansiyonel ürünlerle aynı fiyattan satılması en önemli kısıtlayıcı olarak tespit edilmiştir. Dolayısıyla insan sağlığına faydalı, toprak ve çevreye zarar vermeden üretim yapılabilmesi için öncelikle organik girdiler kullanılarak elde edilen ürünlerin piyasasının oluşturulması sağlanmalıdır. Tüketicilerin bilinç düzeylerinin arttırılması, organik ürünlerin tüketiminin teşvik edilmesi ve organik üretime verilen desteklemelerin artııılarak üretim maliyetlerinin düşürülmesi sağlanarak sürdürülebilir tarımsal üretim sistemleri yaygınlaştıılabilecektir. Yaptığımız çalışmadan elde ettiğimiz sonuçlara göre, organik mısır yetiştiriciliğinde verimin ticari gübre verilen parsellere göre düşük olmasına karşın elde edilen ürünlerin organik olarak satılabilmesi durumunda ekonomik olarak daha karlı olduğu tespit edilmiştir. Ticari gübre kullanımı sonucunda ortaya çıkacak olumsuzlukları göz önüne aldığımızda buna alternatif olarak İyi Tarım Uygulamaları (iTU) insan ve hayvan sağlığına zarar vermeyen, çevre dostu tarımsal bir üretimin benimsendiği, tarımda izlenebilirlik ve sürdürebilirliğin sağlandığı, doğal kaynakların korunmasının ve gıda güvenliğinin amaçlandığı bir üretim modelinin gerçekleştirilmesi önerilebilir. İyi tarım uygulamalarında, kimyasal gübre ve ilaç kullanımı belirli bir program dâhilinde azaltılarak, tarımsal faaliyetlerden kaynaklanan çevresel zararın en aza indirilmesi hedeflenebilir.

\section{ÇIKAR ÇATIŞMASI}

Yazarlar arasında herhangi bir çıkar çatışması bulunmamaktadır.

\section{YAZAR KATKISI}

Tüm yazarlar projenin hazırlanması, yürütülmesi ve yazılmasında görev almıştır.

\section{KAYNAKLAR}

Acar, M., Dok, M., \& Caner, Y. K. (2009). Organik ve geleneksel tarım metodu ile üretilen nohut'un verim, maliyet ve kalite kriterleri bakımından karşılaştırılması. 1. GAP Organik Tarım Kongresi, Karadeniz Tarımsal Araştırma Enstitüsü, Samsun.

Acıbuca, A. (2015). Mardin ekolojik koşullarında II. ürün olarak yetiştirilen kimi mısır çeşitlerinin hasıl ve dane verimi ve verim özellikleri üzerinde araştırmalar. Yüksek Lisans Tezi. Ege Üniversitesi Fen Bilimleri Enstitüsü. İzmir

Akan, S. (2017). Muş ili ekolojik şartlarına uygun tane mısır (Zea mays l.) çeşitlerinin belirlenmesi. Yayınlanmamış Yüksek Lisans

Tezi. Bingöl Üniversitesi. Fen Bilimleri Enstitüsü. Bingöl.

Anonim, (2020). Mardin 2020 yılı meteoroloji bülteni. Mardin Meteoroloji II Müdürlüğü.

AOAC, (1980). Official Methods of Analysis. 13th Edition, Association Official Analytical Chemists, Washington DC. 
Ashoka, P., Anand, S. R., Mudalagiriyappa, P., \& Smitha, R. (2009). Effect of macro and micronutrients with organics on growth, quality, yield and economics of baby corn (Zea mays l.) in tungabhadra command area. Crop Research, 37, 15-18

Aydeniz, A., \& Brohi, A. (1991). Kümes artıkları ve kuş dışkısı. II. Ulusal Gübre Kongresi, Ankara.

Bamire, A. S., \& Amujoyegbe B. J., (2004). Economics of poultry manure utilization in land quality improvement among integrated poultry-maize holder farmers in Southwestern Nigeria. Journal of Sustainable Agriculture, 23(3), 21-37.

Başar, H. (2009). Tavuk gübresi topraklarda nasıl uygulanmalıdır. Bursa'da Gıda ve Tarım, 11, 26-31.

Bek, Y. (1986). Araştırma ve Deneme Metotları. Çukurova Üniversitesi Ziraat Fakültesi Ders Notu, Yayın No: 92, Adana.

Bryan, R. B. (1968). The Development, Use and Efficiency of İndices of Soil Erodibility, Geoderma, 2, 5-25.

Celep, H. (2006). Mısır bitkisinin bazı karakterlerine ön bitki ve farklı azot dozlarının etkisi. Kahramanmaraş Sütçü İmam Üniv. Fen Bil. Ens. Tarla Bitkileri Anabilim Dalı Yüksek Lisans Tezi, Kahramanmaraş.

Cengiz, R, Yanıkoğlu, S., \& Sezer, M. (2010). Sentetik ve organik gübrelerin mısırda (Zea mays l.) verim ve kaliteye etkisi. Organik tarım araştırma sonuçları 2005-2010. T.C. Tarım ve Köyişleri Bakanlığı, Ankara. Turkey.

Cihangir, H., \& Öktem, A., (2016). Bazı organik besin kaynaklarının cin mısıın (Zea mays L. everta) tane verimine etkisi. Journal of Agricultural Sciences, 24(1), 60-71.

Cihangir, H., \& Öktem, A., (2018). Bazı organik besin kaynaklarının cin mısırın (Zea mays L. everta) tane verimine etkisi. Tarım Bilimleri Dergisi. 24(2), 60-67.

Difonzo, N., Motto, M., Maggıore, T., Sabatino, R., \& Salamini, F. (1982). N-Uptake,Translocation and Relationships among NRelated Traits in Maize as Effected by Genotype. Agronomic, 2(9), 789-796.

Dogan, Y., Ekinci, M. B., Togay, N., \& Togay, Y., (2015). Determination of suitable nitrogen doses for growing second product maize (zea mays I.) varieties in chickpea planting fields and its economic analysis. Indian Journal of Agricultural Research. 49(2), 125-133.

Dogan, Y., Togay, N., \& Togay, Y., (2019). Determining irrigation scheduling and different manure sources of yield and nutrition content on maize (zea mays L.) cultivation. Applıed Ecology and Environmental Research, 17(2), 1559-1570.

Dordas, C. A., Lithourgidis, A. S., Matsi, T., \& Barbayiannis, N., (2008). Application of liquid cattle manure and inorganic fertilizers affect dry matter, nitrogen accumulation, and partitioning in maize. Nutrient Cycling in Agroecosystems, 80(3), $283-296$.

Efthimiadou, A., Bilalis, D., Karkanis, A., \& Froud-Williams, B. (2010). Combined organic/inorganicfertilization enhance soil quality and increased yield, photosynthesis and sustainability of sweet maize crop. Australian Journal of Crop Science, 4(9), 722-729.

Elmalı, H., \& Soylu, S. (2008.) Melez at dişi mısırda farklı taban gübresi çeşitlerinin tane verimi, verim unsurları ve kalite üzerine etkileri. Selcuk Journal of Agriculture and Food Sciences, 22(44), 104-112.

Erkoyuncu, C. (2008). Ankara ili Beypazarı ilçesinde organik ve geleneksel olarak yapılan domates yetiştiriciliğinin karşılaştırmalı ekonomik analizi. Fen Bilimleri Enstitüsü. Yüksek Lisans Tezi, Ankara.

FAO. (2020). FAO Statistics Division. Food and Agriculture Organization of The United Nations. http://faostat.fao.org/site/575/ Desktop/Default.aspx?pageID=567\#ancor. Erişim tarihi: 30 Haziran 2020.

Gür, İ. (2019). Trabzon ekolojik koşullarında bazı hibrit atdişi mısır çeşitlerinin performansları. Yayınlanmamış Yüksek Lisans Tezi. Isparta Uygulamalı Bilimler Üniversitesi. Lisansüstü Eğitim Enstitüsü. Isparta.

Kalkan, M. (2008). Farklı mısır olum grupları ve hasat tarihlerinde verim, verim öğeleri ile besin değerleri ve aflatoksin düzeylerinin belirlenmesi. Yüksek Lisans Tezi, Selçuk Üniversitesi, Fen Bilimleri Enstitüsü, Konya.

Khan, H. Z., Malik, M. A., \& Saleem, M. F., (2008). Effect of rate and source of organic material on the production potential of spring maize (Zea mays l.). Pakistan Journal of Agricultural Sciences, 45(1), 40-43.

Kırtok, Y. (1998). Mısır: Üretimi ve Kullanımı. Kocaoluk Basım ve Yayınevi. İstanbul.

Koca, Y. O. (2009). Aydın bölgesinde, birinci ve ikinci ürün mısırda (Zea mays l.) verim, verim öğeleri, fizyolojik ve diğer bazı özellikler arasındaki farklılıklar. Doktora Tezi, Adnan Menderes Üniversitesi, Fen Bilimleri Enstitüsü, Aydın. 
Konuşkan, Ö., Atış, İ., \& Gözübenli. H., (2015). Hatay amik ovası ana ürün koşullarında bazı atdişi mısır çeşitlerinin verim ve verimle ilişkili özellikleri. Mustafa Kemal Üniversitesi Ziraat Fakültesi Dergisi, 20(2), 1-6.

Korkmaz, A., Kızılkaya, R., Horuz, A., \& Sürücü, A., (1999). Mısır bitkisine uygulanan tavuk gübresinin amonyum sülfat gübresine eşdeğer miktarının belirlenmesi, Karadeniz Bölgesi Tarım Sempozyumu, Ondokuz Mayıs Üniversitesi Ziraat Fakültesi, Samsun.

Mitchell, C. C., \& Tu, S., (2005). Long-term evaluation of pultry litter as a source of nitrogen for cotton and corn. Agronomy Journal, 97, 399-407

Morris, D. R., \& Lathwell, D. J., (2004). Anaerobically digested dairy manure as fertilizer for maize in acid and alkaline soils. Communications in Soil Science and Plant Analysis, 35, 1757-1771

Neill, M., \& Robinson, K., (2001). NMSU Testing organic alternative to chemical fertilizers. New Mexica State University Research Bulletins, 6, 2194-2195.

Öner, F., Aydın, İ., Sezer, İ., Gülümser, A., Özata, E., \& Algan, D. (2011). Bazı silajlık mısır çeşitlerinde verim ve kalite özelliklerinin belirlenmesi. Türkiye 9. Tarla Bitkileri Kongresi, Bursa.

Özata, E., Geçit, H. H., Öz, A., \& İkincikarakaya, S. Ü. (2013). Atdişi hibrit mısır adaylarının ana ürün koşullarında performanslarının belirlenmesi. Iğdır Üniversitesi Fen Bilimleri Enstitüsü Dergisi, 3(1), 91-98.

Özdemir, N. (1991). Toprağa karıştııılan organik artıkların toprağın bazı özellikleri ile strüktürel dayanıklılığı ve erozyona duyarlıı̆̆ üzerine etkileri. Atatürk Üniversitesi Ziraat Fakültesi Dergisi, 24(1), 56-61.

Özmen, İ. (2008). Bazı melez mısır çeşit ve genotiplerinin değişik ekim bölgelerindeki adaptasyon ve uyum yeteneklerinin belirlenmesi üzerine araştırmalar. Doktora tezi. Ege Üniversitesi, Fen Bilimleri Enstitüsü, Tarla Bitkileri Anabilim Dalı, İzmir.

Öztürk, Y., Özata, E., Erdal, Ş., \& Pamukçu, M. (2019). Türkiye'de özel mısır tiplerinin kullanımı ve geleceği. Uluslararası Doğu Akdeniz Tarımsal Araştırma Enstitüsü Dergisi, 2(1), 75-90.

Prasanna, K., Halepyati, A. S., Desai, BK., \& Pujari, B. T. (2007). Effect of integrated nutrient management on the productivity and nutrient uptake by maize (Zea mays L.). Karnataka Journal of Agricultural Sciences, 20(4), 833-834.

Qasim, M., Javed, N., Himayatullah, M., \& Subhan, M. (2001). Effect of sewage sludge on the growth of maize crop. Journal of Biology Science, 1(2), 52-54.

Sezer, İ., \& Gülümser, A. (1999). Çarşamba ovasında yetiştirilebilecek mısır çeşitlerinin (zea mays l.) belirlenmesi üzerine bir araştırma. Türkiye III. Tarla Bitkileri Kongresi, Adana.

Sezer, İ., \& Yanbeyi S. (1997). Çarşamba ovasında yetiştirilen cin mısırda (Zea mays L.) bitki sıklı̆ı ve azotlu gübrenin tane verimi, verim komponentleri ve bazı bitkisel karakterler üzerine etkisi. Türkiye II. Tarla Bitkileri Kongresi. On Dokuz Mayıs Üniversitesi Ziraat Fakültesi, Samsun.

Shen, W. B., \& Yang, H. Q. (2008). Effects of earthworm and microbe on soil nutrients and heavy metals. Agricultural Sciences in China, 7(5), 599-605.

Sözüdoğru, S., Karaca, A., \& Haktanır, K. (1996). Tavuk gübresinin azot mineralizasyonu ve üreaz aktivitesi üzerine etkisi. Ankara Üniversitesi Ziraat Fakültesi Yayınları, Yayın No: 1445, Ankara.

Şahin, G. (2016). Türkiye'de Gübre Kullanım Durumu ve Gübreleme Konusunda Yaşanan Problemler. Tarım Ekonomisi Dergisi $22(1), 19-32$.

Tagem. (2020). Tarımsal Araştırmalar ve Politikalar Genel Müdürlüğü. https://www.tarimorman.gov.tr/TAGEM/Belgeler/yayin/G\%C3\%BCbre\%20Sekt\%C3\%B6r\%20Politika\%20Belgesi\%2020182022.pdf Erişim: 14 Temmuz 2020.

TMO. (2017). Toprak Mahsulleri Ofisi Genel Müdürlüğü. 2016 Yılı Hububat Sektör Raporu. http://www.tmo.gov.tr/Upload/Document/hububatsektorraporu2016.pdf Erişim: 14 Temmuz 2020.

TOB. (2016). Mardin Tarım ve Orman İı Müdürlüğü, Mardin İli Artuklu İlçesi 2016 Yılı Sulu ve Sulanabilir Arazilerde Mısır (Dane) Maliyet Cetveli.

TÜiK. (2020). Türkiye İstatistik Kurumu. https://biruni.tuik.gov.tr/medas/?kn=104\&locale=tr Erişim: 18 Temmuz 2020. 
Doğan ve ark., II. Ürün Mısır Çeşitlerinde Organik ve İnorganik Gübre Uygulamasının Verim ve Kaliteye Etkisi ile Ekonomik

Uzun, A., Öz, M., Karasu, A., Başar, H., Turgut, İ., Göksoy, A.T., \& Açıkgöz, E. (2005). Yeşil yem ve gübreleme amacıyla yetiştirilen adi fiğ (Vicia sativa l.)'den sonraki mısırın verim özellikleri. Uludağ Üniversitesi Ziraat Fakültesi Dergisi, 19(2), 83-96.

Warman, P .R., \& Havard K. A. (1998). Yield vitamin and mineral contents of organically and conventionally grown potatoes and sweet corn. Agriculture, Ecosystem and Environvant, 68, 207-216.

Yılmaz, H. A., \& Dokuyucu, T. (1994). Kahramanmaraş koşullarına uygun ve yüksek verimli makarnalık buğday çeşitlerinin saptanması. Tarla Bitkileri Kongresi, İzmir. 